J. Product. \& Dev., 23(1): 135-145 (2018)

\title{
TECHNOLOGICAL EFFECTS OF LEMON, SWEET ORANGE JUICE AND ASCORBIC ACID AS SUPPLEMENTS ADDITIVE ON MULBERRY SILKWORM LARVAE, Bombyx mori L.
}

Walaa Sallam $^{1}$, F . El-Santeel ${ }^{1}$.; EL-Sharkawy, $H^{1}$. and Saad, $M^{2}$.

1. Department of Plant Production, Faculty of Technology \&Development, Zagazig University, Egypt

2. Plant Protection Research Institute, A.R.C., Dokki, Giza, Egypt.

\section{ABSTRACT:}

The present investigations were carried out during two spring seasons, 2015- 16 in the silkworm laboratory of Sericulture Department of Plant Protection Research Institute, Sharkia Branch to investigate the effect of 4 concentrations of lemon, sweet orange juice and ascorbic acid $(1 \%, 2 \%, 3 \%, 4 \%)$ on silk production of mulberry silkworm Bombyx mori L.

The obtained results cleared that the highest concentration (4\%), for lemon juice sweet orange juice and ascorbic acid gave the highest mean of fresh cocoon weight, shell cocoon weight and silk ratio. On the other hand, the high concentration of sweet orange (4\%) recorded the highest mean of silk filament weight and size, whereas the highest concentration (4\%) of ascorbic acid and lemon gave the highest mean of silk filament length. Lemon juice, sweet orange juice and ascorbic acid improved cocoon indices and silk filament characters as a profitable supplementary diet for silk worm Bombyx mori L.

Conclusively, the highest concentration (4\%) of ascorbic acid and lemon gave the highest mean of silk filament length. Lemon juice, sweet orange juice and ascorbic acid improved cocoon indices and silk filament characters as a profitable supplementary diet for silk worm Bombyx mori L.

Keywords: Lemon, Sweet Orange Juice, Ascorbic Acid, Mulberry Silkworm Larvae, Bombyx Mori L.

\section{INTRODUCTION}

Mulberry silkworm, Bombyx mori is one of the most economically important insects not only on the national level but also internationally. The development of sericulture is directly related to the mulberry cultivation as the mulberry silkworm is an insect of monophagous characteristics that eats only 
mulberry leaves. Therefore, much efforts and researches must be involved in the quantitative and qualitative production of mulberry leaves for silkworm rearing and cocoon production (Raman et al., 1995).

Silk production depends on the quality and nutritional status of the mulberry leaf. Recently, the enrichment of mulberry leaf with a multitude of exogenous factors. Such as vitamins, minerals, antibiotics and hormones and study mandated the order of traditional in sericulture. One important nutrient that attracts the attention of researchers in this field is vitamins $\mathrm{C}$ or L- ascorbic acid. This vitamin is present in the mulberry leaf and plays many vital roles in Bombyx mori (Lombardi, 1964). It has been identified as a powerful anti-oxidant, potential phage stimulant, efficient growth promoter and booster of silk production in the silk worm (Ito, 1961; Javed and Gondal, 2002; Hussain and Javed, 2002; Prasad 2004; Etebari et al., 2004, Etebari and Matindoost 2005).

It is known that there is a high correlation between the leaf protein level and production efficiency of the cocoon shell, which means the cocoon shell weight of the total amount of mulberry leaves consumed by the silkworm (Machii and Katagiri, 1991). Therefore, an increase in the protein level of mulberry leaves may lead to improvements in silk productivity.

Egypt produces 3 tons of raw natural silk each year, while the local market needs more than 300 tons that must be imported from abroad, so a considerable attention has been given recently to improve rearing of this insect and to increase the production of raw natural silk. Also, the production of high quality and quantity of natural silk depends mainly on larval feeding (Parra, 1991), suitable environmental conditions (Saha and Khan 1996), and protection from diseases (Dechu et al., 1997).

Literature review reveals that the nutritional- enrichment studies were based largely on the application of expensive commercial sugar, proteins, vitamins and minerals. The combined effects of most of these exogenous nutrients could be achieved through a single natural nutrient, called the lemon juice, which is a rich source of multiple vitamins and minerals (Markus and Sass, 2003). Further, lemons are perennial and inexpensive fruits, readily available in all seasons. Despite its high nutritional value, their impact of lemon juice has not been examined with reference to silkworm growth and economic parameters of sericulture. Citrus flavonoids have a large spectrum of biological activity, including antibacterial, antifungal, antidiabetic, anticancer and antiviral activities (Ortuno et al., 2006).

Therefore, the present study aimed to evaluate the effect of the lemon juice, sweet orange juice and ascorbic acid as nutritional additives on silkworm Bombyx mori to improve its growth and productivity as health maintenance or growth promotion. 


\section{MATERIALS AND METHODS}

The present investigations were carried out during 2 spring seasons, 2015 and 2016 in silkworm laboratory of Sericulture Department of Plant Protection Research Institute, Sharkia Branch.

\section{Used Materials}

a) Native mulberry leaves Morus alba variety (Balady)

b) Mulberry silkworm, Bombyx mori L. (H1*KK*G2*V2).

c) Ascorbic acid $100 \%$ (W.P.).

d) Natural products (Lemon juice, (Citrus aurantiifolia) and sweet orange juice (Citrus Sinensis L.).

Eggs of silkworm Bombyx mori L. were obtained from the Sericulture Research Department of Plant Protection Research Institute, Agriculture Research Center, Ministry of Agriculture and Land Reclamation in Giza, Egypt.

The following experiments were carried out:

\section{- Feeding Technique}

The tested materials were used solely at 4 concentrations each as follows:

- Ascorbic acid (As) at 1\%, 2\%, 3\%, 4\%.

- Lemon juice at $1 \%, 2 \%, 3 \%, 4 \%$.

- Sweet orange juice at $1 \%, 2 \%, 3 \%, 4 \%$.

Three replicates of 50 silkworm larvae each were fed, throughout $4^{\text {th }}$ instar on mulberry leaves dipped on the tested concentrations of each material for 1 minute then left to dry under laboratory conditions. As well as 3 replicates treated with distelled water as control, larvae of each replicate were reared on a plastic tray $(100 \times 70 \times 15 \mathrm{~cm})$ under a controlled rearing room at $27 \pm 2{ }^{\circ} \mathrm{C}$ and $95 \pm 5 \% \mathrm{Rh}$ for the first three instar (1-3), while it was changed in the last two (Fourth and Fifth) instar to $24 \pm 2{ }^{\circ} \mathrm{C}$ and $75 \pm 5$ $\% \mathrm{RH}$. All the rearing room trays, racks and tools, rearing rooms as well as the rearing places were sterilized with formalin $(5 \%)$ one week before the beginning of the experiment. The test larvae were offered to feed/day at 8 am, 12 noon, $4 \mathrm{~h}$ and $8 \mathrm{pm}$. The survived larvae were fed during their $5^{\text {th }}$ instar on untreated mulberry leaves.

Mature larvae were handily transferred to carton paper (that used wrapping Table eggs), Zannon and Shadia (1994) for mounting process. The cocoons were harvested seven days later. Five fresh cocoons of the resulted cocoons of each replicate were taken for measuring the cocoon indices (fresh cocoon weight, cocoon shell weight and silk content ratio) whereas, 
dried in an oven (oven temperature was raised gradually until it reached 80 $\mathrm{C}^{\mathrm{o}}$ for 6 hours). The rest of the cocoons were dried to study filament characters \{ filament length $(\mathrm{m})$, filament weight $(\mathrm{g})$ and filament size $(\mathrm{dn})\}$.

\section{Dipping leaf technique:}

On this trail, the leaf dipping technique was used to evaluate the effect of doses of some concentrations of the tested products on the $4^{\text {th }}$ instar larvae. The dipped leaves were left to dry and provided to larvae (50 larvae) in three replicates for each concentration treatments and control. Therefore, the survived larvae were fed on untreated mulberry leaves. The productivity measures were investigated.

\section{Measurements:}

The following technological parameters were measured in both experiments as follow:

\section{1-Cocoon indices:}

The following parameters were measured:

A- Fresh cocoon weight (g).

B- Cocoon shell weight $(\mathrm{g})$.

C- Silk ratio $=\frac{B}{A} \times 100 \quad$ (Krishnaswami, 1978)

\section{2-Reelable silk filament parameters:}

The weight (mg) and length $(\mathrm{m})$ of reeled silk filament were measured and recorded.The size of the reeled filament (denier) was estimated according to (Krishnaswami, 1978) formula:

The size of reeled filament $=\frac{\text { weight of reeled filament }(\mathrm{mg})}{\text { Length of reeled filment }(\mathrm{m})} \times 9000$

Data obtained were statistically analyzed according to Snedecor and Cochran (1982) methods using the software COSTAT program.

\section{RESULTS AND DISCUSSION}

\section{Cocoon indices}

Fresh cocoon weight (g):

Data presented in Table (1), cleared that the heaviest weight of fresh cocoon was gained from the larvae fed on mulberry leaves enriched with Lemon (4\%), as it recorded 2.10 and $2.05 \mathrm{~g}$ in 2015 and 2016 seasons, respectively ( $\chi=2.08 \mathrm{~g}$ ). Meanwhile, control cocoons recorded a two years 


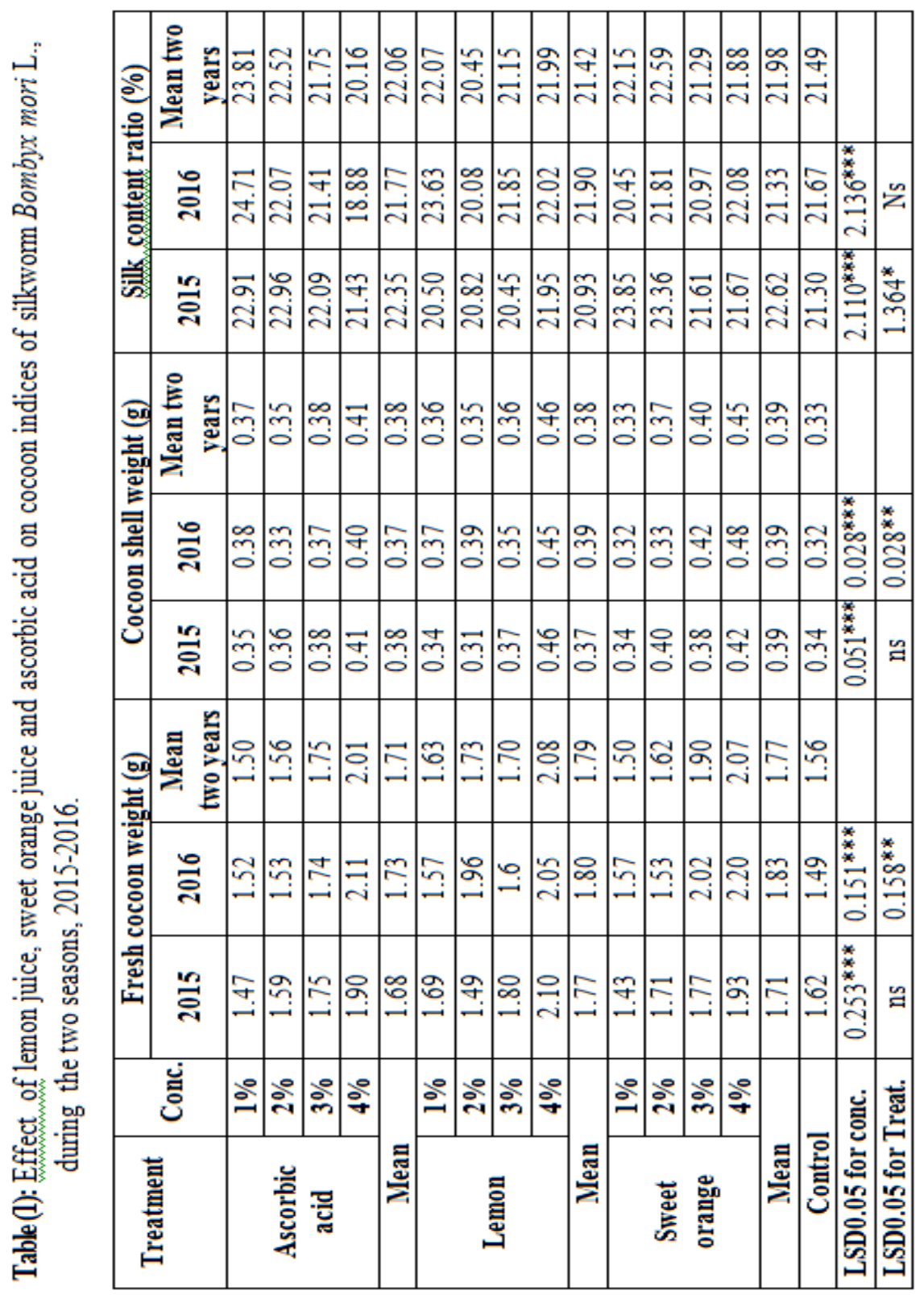


mean weight of $1.56 \mathrm{~g}$. Generally, and according to the two years mean Lemon treatments were the superior $(2.08 \mathrm{~g} /$ cocoon $)$ followed by sweet orange treatments $(2.07 \mathrm{~g} / \mathrm{cocoon})$ regardless of the concentration.

\section{Cocoon shell weight $(g)$ :}

As shown in Table (1), the heaviest cocoon shell weight was recorded for the cocoons spun by $B$. mori larvae fed during their $4^{\text {th }}$ instar on mulberry leaves fortified with Lemon (4\%.), recording $0.46 \mathrm{~g}$ in 2015 but $0.48 \mathrm{~g}$ for sweet orange (4\%) in 2016 compared to 0.34 and $0.32 \mathrm{~g}$ for the control cocoons. Respectively, lemon treatments proved to be the most potent, followed, in descending order, by sweet orange and ascorbic acid treatments. However, all the tested additives improved these parameters over the control.

\section{Silk content ratio:}

Obtained results in Table (1) cleared that the highest silk content ratio in both seasons were recorded for the cocoon spun by B. mori larvae fed in $4^{\text {th }}$ instar on mulberry leaves enriched with ascorbic acid $(1 \%)$, in the two years means the silk content ratio attained $23.81 \%$. Generally, the treatments of ascorbic acid proved to be the superior followed by sweet orange treatments $(21.98 \%)$. On the other hand, control treatment recorded silk ratio of $21.49 \%$.

\section{Reeled silk filament parameters: Silk filament length (m):}

As shown in Table (2), the highest two years mean length of reeled silk filament of cocoon spun by $B$. mori larvae fed during $4^{\text {th }}$ instar on treated mulberry leaves with ascorbic acid $4 \%(1446.40 \mathrm{~m})$, followed by lemon (4\%), recording $1401.92 \mathrm{~m}$. On the other hand, control cocoon gave $1106.40 \mathrm{~m}$. In addition, all the tested additives caused significant prolongation in silk filament length as compared to the control.

\section{Silk filament weight $(g)$ :}

As shown in Table (2) the heaviest two years mean reeled silk filament weight were recorded for the cocoons spun by B. mori larvae fed on sweet orange $(4 \%)$ recording $0.37 \mathrm{~g}$, followed by that of the larvae offered enriched mulberry leaves with lemon juice (4\%) and ascorbic acid (3\%) recording $0.35 \mathrm{~g}$. Meanwhile, control silk filament weighed $0.24 \mathrm{~g}$. On the other hand, the highest mean of treatment was ascorbic acid recording $0.33 \mathrm{~g}$ followed by sweet orange juice $0.32 \mathrm{~g}$. 


\begin{tabular}{|c|c|c|c|c|c|c|c|c|c|c|c|c|c|c|c|c|c|}
\hline 흔 & 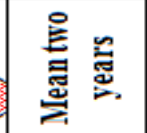 & 2 & & & U. & s. & & $\underset{\sim}{\vec{i}}$ & শ্রি & స્ડి & & $\stackrel{\leftrightarrow}{\stackrel{\leftrightarrow}{\sim}}$ & రి & $\underset{i}{0}$ & $\stackrel{\Omega}{\therefore}$ & & \\
\hline 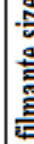 & 윽 & D্ & $\infty$ & & & $\hat{s}$ & 政 & $\stackrel{i}{i}$ & $\stackrel{\overbrace{}}{\sim}$ & 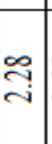 & 洽 & $\stackrel{\check{\sim}}{\circ}$ & $\vec{\infty}$ & $\vec{\sim}$ & $\stackrel{-}{-\infty}$ & 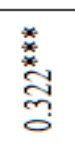 & $\stackrel{\text { 絭 }}{\stackrel{5}{0}}$ \\
\hline 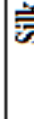 & 䄏 & $\overrightarrow{-}$ & 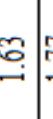 & & : & & $\approx$ & i & $\stackrel{\circ}{\sim}$ & $\underset{\sim}{\Xi}$ & ন্ & 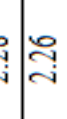 & $\underset{\sim}{\stackrel{\sim}{\sim}}$ & $\vec{m}$ & $\underset{\sim}{*}$ & 焉 & 落 \\
\hline & 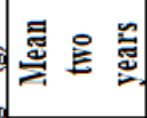 & $\overline{0}$ & $\tilde{c}$ & $\hat{m}$ & $\tilde{s}$ & 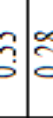 & $\tilde{\varepsilon}$ & $\stackrel{\infty}{0}$ & $\approx$ & $\vec{m}$ & 尾 & $\stackrel{2}{0}$ & $\bar{m}$ & సิ & $\stackrel{\Delta}{0}$ & & \\
\hline . & 옥 & $\vec{m}$ & $\tilde{b}$ & $\vec{m}$ & 6 & 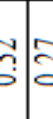 & $\bar{c}$ & 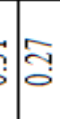 & సె. & సి & $\overrightarrow{0}$ & $\vec{m}$ & $\begin{array}{l}\infty \\
m \\
0\end{array}$ & స̂. & $\tilde{\Xi}$ & 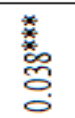 & 荬 \\
\hline$\frac{5}{\bar{y}}$ & 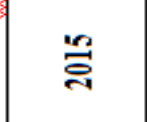 & তি & 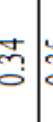 & $\hat{b}$ & 3 & 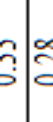 & 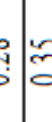 & $\stackrel{\infty}{\infty}$ & $\mid \begin{array}{c}\infty \\
m \\
0\end{array}$ & $\tilde{a}$ & 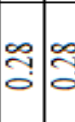 & in & 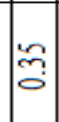 & $\vec{m}$ & 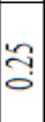 & 蔏 & 旁 \\
\hline $\begin{array}{l}\text { हू } \\
\text { ही }\end{array}$ & 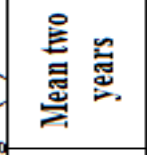 & $\mid$\begin{tabular}{l}
$\mathbf{D}$ \\
0 \\
\hdashline \\
\hdashline \\
\hdashline
\end{tabular} & 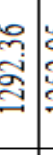 & $\begin{array}{lll}5 \\
b \\
6\end{array}$ & 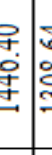 & 菅 & 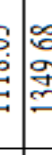 & 壱 & 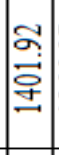 & |̇ & 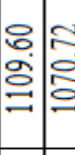 & \begin{tabular}{l}
$\infty$ \\
$\infty$ \\
$\infty$ \\
\hdashline
\end{tabular} & 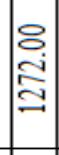 & 胥 & $\begin{array}{l}\text { ㅇ. } \\
\text { ○े } \\
\vdots\end{array}$ & & \\
\hline है & 을 & : & : & م. & 2 & 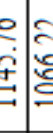 & s. & 竝 & $\mid$ & 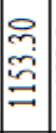 & 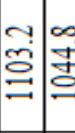 & 咅 & 命 & $\begin{array}{l}\stackrel{ \pm}{\infty} \\
\stackrel{\Xi}{\Xi} \\
\end{array}$ & 응 & 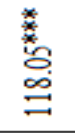 & 惫 \\
\hline$\frac{1}{y}$ & 茎 & \begin{tabular}{c} 
to \\
$\vdots$ \\
$\vdots$ \\
\hdashline \\
\hdashline
\end{tabular} & $\begin{array}{l}\text { 寺 } \\
\text { : } \\
\end{array}$ & 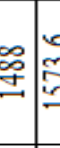 & : & 事 & 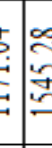 & 象 & 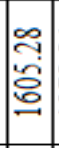 & $\begin{array}{l} \pm \\
\infty \\
\infty \\
0 \\
- \\
\end{array}$ & 曋 & 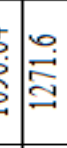 & \begin{tabular}{l}
$\infty$ \\
0 \\
0 \\
\hdashline \\
\hdashline \\
\end{tabular} & 瓷 & 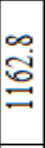 & 奎 & 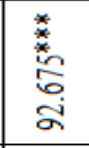 \\
\hline & ٍ̆ & $\therefore$ & $\stackrel{\circ}{\circ}$ & ¿ें & $\stackrel{0}{*}$ & $\vdots$ & 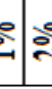 & $\stackrel{\circ}{\circ}$ & $\stackrel{0}{\circ}$ & & $\therefore$ & जे & $\stackrel{\circ}{\circ}$ & & & & \\
\hline & 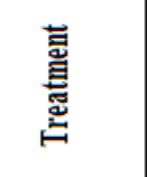 & & 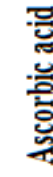 & & & 芯 & & 臣 & & 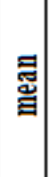 & & 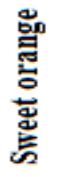 & & : & 홍 & 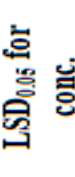 & 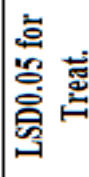 \\
\hline
\end{tabular}




\section{Silk filament size $(\mathrm{dn})$ :}

Data presented in Table (2) revealed that the highest two years mean size of reeled silk filament $(2.62 \mathrm{dn}$.) was recorded for the larvae fed on mulberry leaves treated with sweet orange $(4 \%)$, followed by that of larvae fed on sweet orange (3\%), recording $2.45 \mathrm{dn}$. Control silk filament size attained $2.15 \mathrm{dn}$. The differences between means were mostly significant in both seasons.

Lemon juice, the extract of the yellow fruit of Citrus limen (Family: Rutaceae), is a natural and most popular multi-factorial nutrient. It is a rich source of vitamin-C (64\%) and B-complex vitamins such as pantothenic acid $(4 \%)$ as folic acid (3\%), thiamine (3\%), riboflavin $(2 \%)$ and niacin $(1 \%)$. Additionally, it in-cludes carbohydrates, sugars, lipids, proteins, minerals $(\mathrm{Ca}$, $\mathrm{Fe}, \mathrm{Mg}, \mathrm{P}, \mathrm{K}, \mathrm{Zn}$ etc) and some organic acids (Markus and Sass, 2003; Albertini et al., 2006). Needless to say, it plays a vital role in the growth and metabolism of organisms, a fact that has been amply demonstrated in $B$. mori in its larval growth, protein profles and economic traits of sericulture.

Conclusively, the best result cleared that the highest concentration (4\%), for lemon juice sweet orange juice and ascorbic acid gave the highest mean of fresh cocoon weight, shell cocoon weight and silk ratio and the highest concentration (4\%) of ascorbic acid and lemon gave the highest mean of silk filament length. Lemon juice, sweet orange juice and ascorbic acid improved cocoon indices and silk filament characters.

\section{REFERENCES}

Aabid K. T. and T. Kanika (2011). Significance of application time for dietary vitamin $\mathrm{C}$ supplementation in the silkworm, Bombyx mori L. Current Biotica (www.currentbiotica.com).Vol 4 (4): 419-425.

Albertini, M.V., Carcout, E., Pailly, O., Gambotti , C., Luro, C.F., \& Berti L. (2006). Changes in the organic acids and sugars during early stages of development of acidic and acid less citrus fruits. Journal of Agricultural and Food Chemistry, 54(21): 8335-8339.

Dechu, P.S., Govindan, R., Devaiah, M. C. and Narayanaswamy ,T.K. 1997. Effect of antibiotic on growth and cocoon parameters of silkworm Bombyx mori L. Mysore J. Agric. Sci., 31:41-46.

El- Karaksy, I.A., and M. Idriss. (1990). Ascorbic acid enhances the silk yield of mulberry silkworm, Bombyx mori, L. Indian Journal of Applied Entomology, 109: 81-86. 
Etebari K. and L. Matindoost (2005). Application of multi-vitamins as supplementary nutrients on biological and economical characteristics of silkworm Bombyx mori L. J. Asia-Pacific Entomol. 8(1): 107 -112.

Etebari, K.; R. Ebad and L. Matindoost (2004). Effect of feeding mulberry's enriched leaves with ascorbic acid on some biological, biochemical and economical characteristics of silk worm, Bombyx mori L., Int. J. Indust. Entomol., 8: 81-87.

Ganesh P. P., D. B., Selvi, V. Mathivanan and V. Ramesh (2013). Biotechnological applications and nutritional supplementation of ascorbic acid (Vitamin C) treared Morus alba (L.) leaves fed by silkworm, Bombyx mori L. Lepidoptera: Bombycidae) in relation to silk production. International Journal of Research in Biomedicne andBiotechnolgy, 3(1): 11-16, 2013.

Hussain, M. and H. Javed (2002). Effect of $0.2 \% \mathrm{~N}$ with various combination of ascorbic acidon growth and silk production of silkworm, Bombyx mori L. Asian J. Plant Sci., 1(6), 650-651.

Ito, T. (1961). Effect of dietary ascorbic acid on the silkworm, Bombyx mori. Nature. 4806(192): 951-952.

Javed, H., \& Gondal ,M.H.(2002). Effect of food Supplementation by N and Ascorbic acid on larval mortality of silkworm (Bombyx mori L.). Asian J. Plant Sci., 1: 556-557.

Krishnaswami, S. (1978). New technology of silkworm rearing. Central Sericulture Researches and Training Institute. Mysore Bull, (2): 1-10.

Lombardi, P. L. (1964). Comportamento del gelsokosukonelperiodo di acclimatazione in Italia. Ann. Staz.Bacol. Sper. Padova. 52: 407-432.

Machii K. and Katagiri K. (1991): Varietal differences in nutritive values of mulberry leaves for rearing silkworms. Japan Agricultural Research Quarterly, 5:23-27.

Markus , M.T., and M. Sass (2003). Chemicl composition of citrus fruits (Orange, Lemon and Grape fruit) with respect to quality control of juice Products. Nutraceutical Beverages, 887: 24-34.

Ortuno, A., A. Baidez, P. Gomez, M.C. Arcas, A. Garcia-Lidon and R. JAdel (2006). Citrus paradise and Citrus sinensis flavonoids: Their influence in the defense mechanism against Penicillium digitatum. Food Chem., 98: 351-358.

Parra, J. R.P.(1991).consume utilizacao de alimentos por insetos, In: PANIZZI, A.R., Parra, J. R. P. Ecologia nutricional de insetose saus Implicaacoes no manejo de pragas., 359 p.Manole, sao Paulo. 
Prasad, P. R. (2004): Effect of fortification of ascorbic acid through mulberry leaf on cocoon traits of Pure Mysore race of silkworm Bombyx mori L. Indian Journal of Entomology, 66(1):37-39.

Raman, k. V., Mala, V. R., Magadum, S. B. and Datta, R. K. ( 1995). Effect seasons and mulberry varieties on the feed conversion efficiencies of different silkworm hybrids of Bombyx mori L. Ulttar Pradesh Journal of Zoology., 15 (3): 157-161.

Saad, M.S.I.(2016).Biological and productivity characters of mulberry silkworm, Bombyx mori L. fed on leaves treated with lemon juice and antibiotic e-mox. Minufiya J. Agric. Res., 41 (2):459-467.

Saha, B. and A. Khan (1996). Effect of dietary supplementation of vitamins and minerals on the growth and development of Bombyx mori. Bang. $J$. Zool., 24: 125-131.

Sengupta, K.; B.D. Singh and J. C. Mustafi (1992). Role of vitamins in silkworm nutrition. Indian J. of Seri., 11(1): 11-19.

Singh, A., and S. B. Ahmed (2012). Supplementation of synthetic vitamin C in the fifth instars Bivoltine hybrid larvae of NB4 D2 X SH6 of silkworm, Bombyx mori L. International Journal of Food, Agriculture and Veterinary Sciences, 2 (1): 54-57.

Snedecor, G. W. and Cochran, W. G. (1982). Statistical Methods. Iowa State Univ. Press, Amer. Iowa.

Thulasi ,N., and Sivaprasad, S. (2013). Synergetic effect of ascorbic acid and lemon juice on the growth and protein synthesis in the silkworm, Bombyx mori and its influence on economic traits of sericulture. J. Bio. Innov., 2(4): 168-183.

Thulasi, $\mathbf{N}$ and Sivaprasad, $\mathbf{S}$ (2014). Impact of feeding lemon juice-enriched mulberry leaves on the larval growth, protein profles and economic traits in the silkworm, Bombyx mori. Indian Journal of Applied Research, Vol(4): 2, 36-44.

Zannoon A. A. and Sh Omara (1994). Efficiency of certain natural materials as mountages for mulberry silk worm Bombyx mori L. Egypt. J. App. Sci., 9(8): 691-696. 


\section{التاثيرات التكنولوجية لعصير الليمون والبرتقال البلدي وحمض الاسكوربيك}

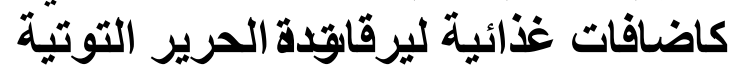

ولاء سلام 1 ، فتحى السنطيل1 ، حمزة محمد الشرقاوي 1، محمود سعد ابراهيم 2

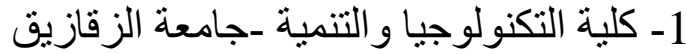

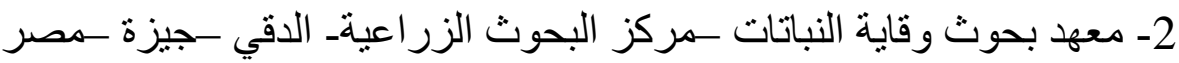

أجريت الدراسة خلال فصل موسمي ربيع 2015- 16 في معمل قسم بحوث

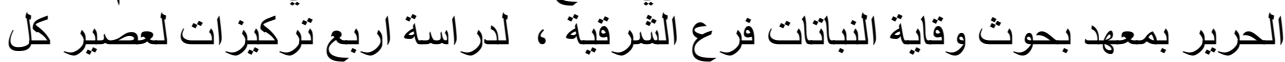

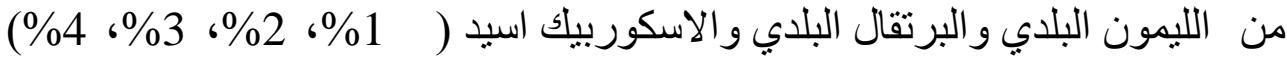

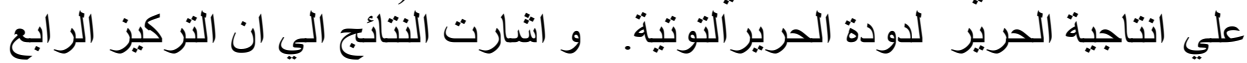

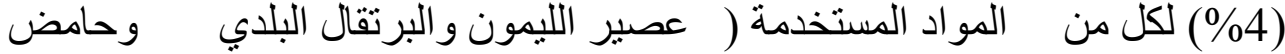

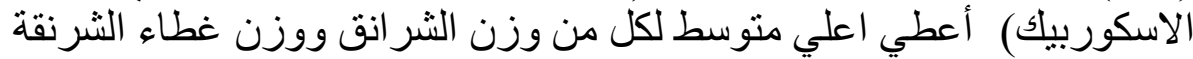

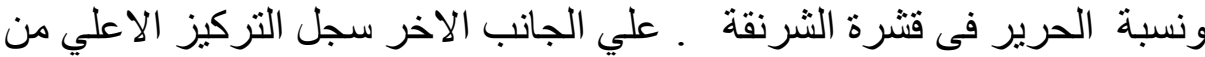

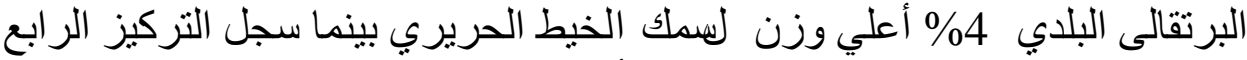

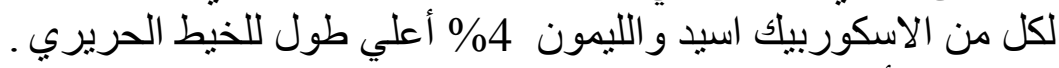
وقد أوضحت التجارب ان استخدام هذه المواد عصير الليمون و عصيرير

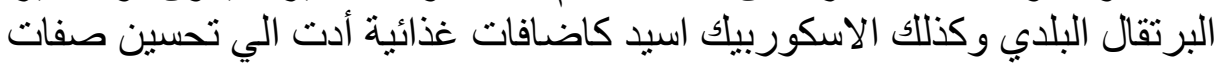
الثر انق و الخيط الحريري كنظام غذائي فعال ليرق ات ديدان

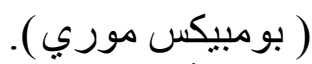

التوصية: نستخلص من النتائج السابقة لهذه الدر اسة ضرورة تلدعيم وتعزيز ورق

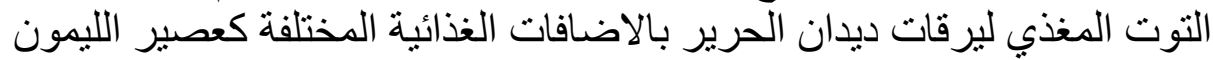

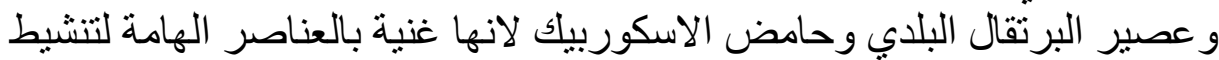

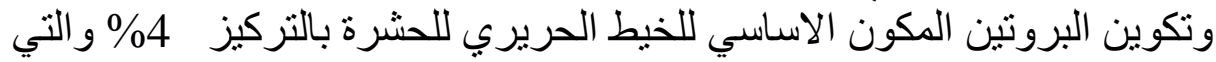

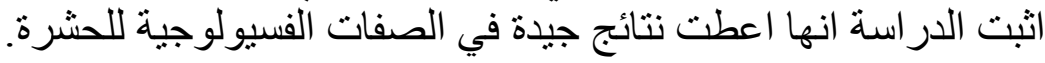

